\title{
CORRIGENDUM
}

\section{Managerial Styles in Privately Owned Domestic Organizations in Russia: Heterogeneity, Antecedents, and Organizational Implications-CORRIGENDUM}

\author{
Evgeniya Balabanova, ${ }^{1}$ Alexey Rebrov, ${ }^{1}$ \\ and Alexei Koveshnikov ${ }^{2}$ \\ ${ }^{1}$ National Research University Higher School of Economics, Russia, and ${ }^{2}$ Aalto University, Finland
}

https://doi.org/10.1017/mor.2017.45. Published online by Cambridge University Press, 23 November 2017

The affiliation for Evgeniya Balabanova and Alexey Rebrov in the article by Balabanova et al. in Management and Organization Review was incomplete in the version published online. The correct affiliation is National Research University Higher School of Economics, Russia, as it appears above.

\section{Reference}

Balabanova, E., Rebrov, A., \& Koveshnikov, A. 2017. Managerial styles in privately owned domestic organizations in Russia: Heterogeneity, antecedents, and organizational implications. Management and Organization Revieze. https://doi.org/10.1017/mor.2017.45. 